\title{
Dead-End (dnd) Gene Cloning and Gonad-Specific Expression Pattern in Starry Flounder (Platichthys stellatus)
}

\author{
Ji-Hye Yoon ${ }^{1}$, Youn-Su Cho ${ }^{2}$, Hyo-Bin Lee ${ }^{1}$, Jung-Yeol Park ${ }^{3}$ and Han-Kyu Lim ${ }^{1, *}$ \\ 1 Department of Interdisciplinary Program of Biomedicine, Health \& Life Convergence Science, \\ Mokpo National University (MNU), Muan 58554, Korea; bdh00258@naver.com (J.-H.Y.); \\ leeehyobin@gmail.com (H.-B.L.) \\ 2 Department of Fishery Biology, Pukyong National University (PKNU), Busan 48512, Korea; \\ whdbstn12@gmail.com \\ 3 Department of Marine and Fisheries Resources, Mokpo National University (MNU), Muan 58554, Korea; \\ jungyeol89@naver.com \\ * Correspondence: limhk@mokpo.ac.kr
}

Citation: Yoon, J.-H.; Cho, Y.-S.; Lee, H.-B.; Park, J.-Y.; Lim, H.-K. Dead-End (dnd) Gene Cloning and

Gonad-Specific Expression Pattern in Starry Flounder (Platichthys stellatus). Animals 2021, 11, 2256. https:// doi.org/10.3390/ani11082256

Academic Editor: Athanasios Exadactylos

Received: 15 June 2021

Accepted: 20 July 2021

Published: 30 July 2021

Publisher's Note: MDPI stays neutral with regard to jurisdictional claims in published maps and institutional affiliations.

Copyright: (c) 2021 by the authors. Licensee MDPI, Basel, Switzerland. This article is an open access article distributed under the terms and conditions of the Creative Commons Attribution (CC BY) license (https:// creativecommons.org/licenses/by/ $4.0 /)$.
Simple Summary: The dead end $(d n d)$ gene encodes an RNA-binding protein that plays a role for migration of primordial germ cells (PGCs) to the gonadal region during embryogenesis in vertebrates. Here, the starry flounder (Platichthys stellatus) dead end ( $p s d n d$ ) gene was characterized and its expression patterns were analyzed. Full-length $p s d n d$ mRNA was 1495 bp long, encoding 395 amino acids. $p s d n d$ was only expressed in gonadal tissues, we detected no psdnd expression in somatic cells. Furthermore, $p s d n d$ was strongly expressed during early embryogenesis. Our findings suggest that $p s d n d$ expression is gonad-specific and could therefore be used as a germ cell marker in starry flounder.

Abstract: dnd is a germline-specific maternal RNA expressed in various vertebrate classes, which encodes an RNA-binding protein that is essential for PGC migration. The purpose of this study is fundamental research about starry flounder $d n d$ gene for germ cell marker development. In this study, we cloned and analyzed the expression levels of Platichthys stellatus dead end ( $p s d n d$ ) in various tissues and embryonic stages. The $p s d n d$ gene was isolated from starry flounder ovaries, cloned into a pGEM-t vector, and sequenced. Full-length of $p s d n d$ cDNA was 1495 bp long, encoding 395 amino acids. psdnd expression levels were investigated by real-time polymerase chain reaction (qRT-PCR) in various tissues and embryo developmental stages. $p s d n d$ transcripts were detected in the testes and ovaries, but not in somatic tissues. Embryonic psdnd expression levels were higher during early embryo development stages than during late embryogenesis; $p s d n d$ expression was highest at the 1 cell stage, then gradually decreased throughout the subsequent developmental stages. The spatial expression pattern was analyzed by whole-mount in situ hybridization (WISH). The $p s d n d$ transcripts migration pattern was similar with zebrafish (Danio rerio). Our results suggest that $p s d n d$ may function as a germ cell-specific marker.

Keywords: dead end; PGC; germ cell; maternal gene; Platichthys stellatus

\section{Introduction}

PGCs are the only cells that can transmit genetic material to the next generation. PGCs move to the gonadal location during early embryogenesis where they develop into gonads [1]. The proliferation of PGCs become the germline stem cells which can develop to mature gonads. Furthermore, migration of PGCs impacts on the fertility [2]. The cell fate and development of PGCs are determined by germ plasm mRNA derived from the maternal line [2]. Maternal germplasm mRNAs encode evolutionarily conserved proteins, including vasa, nanos C2HC-type zinc finger 3 (nanos3), dead-end (dnd), tudor-domain-containing protein 7 ( $t d r d 7)$, and deleted in azzospermia-like (dazl) [2-6]. 
dnd is a germ plasm-specific marker in several vertebrate species that encodes an RNAbinding protein essential for PGC migration [7]. Uracil-rich sequences in the microRNA 430 bind to DND in zebrafish (Danio rerio). dnd prevents the degradation of germ plasm mRNAs targeted by mi430, thus maintaining germ cell development [8].

Germ cell-specific expression of $d n d$ was first discovered in zebrafish after which similar expression patterns were found in various vertebrate species including mice (Mus musculus), frogs (Xenopus tropicalis), chickens (Gallus gallus), and humans (Homo sapiens) [8-11]. Thus, $d n d$ is an evolutionarily conserved gene. In zebrafish and medaka (Oryzias latipes), germ cells are essential for female gonadal differentiation and the absence of PGCs induces sterility in males [12,13]. In addition, the removal of PGCs from pond loach (Misgurnus anguillicaudatus) and goldfish (Carassius auratus) induces sterility both males and females $[14,15]$. Abnormal PGC localization was induced in zebrafish by knocking down dnd expression [12]. In frogs, PGCs were lost when $d n d$ was knocked down using morpholino oligonucleotide [16]. These studies indicate that $d n d$ is essential for germ cell development during embryogenesis.

Most farmed fish reach gonadal maturation before they are released to the market, and gonadal maturation is an important factor that determines the marketability of fish [17]. However, infertile fish exhibit improved growth rates, meat quality, and disease resistance; these effects are achieved by minimizing the energy required for gonadal development [18-22]. In addition, sterilization is an effective method to reduce ecological genetic contamination by protecting natural species from escaped farmed fish, thus maintaining genetic diversity [17].

The development of sterilization strategies is an important goal for researchers. To achieve this, genetic modification techniques such as chromosome manipulation, transgene expression, morpholino oligonucleotide treatment, and CRISPR/Cas9 are increasingly undergoing development and application in the aquaculture industry. dnd knockdowns can induce sterility in organisms by blocking PGC migration to the gonad developmental region. Genetic engineering techniques have been applied to knock-down $d n d$ in channel catfish (Ictalurus punctatus) [23]. Furthermore, salmon were successfully sterilized by targeting dnd with CRISPR/Cas9 [24]. Infertility was induced in sterlet (Acipenser ruthenus) by knocking down $d n d$ with an antisense morpholino oligonucleotide [25].

To support novel technologies for producing infertile eggs in starry flounder, we conducted fundamental research including identification of $p s d n d$ and expression pattern during embryogenesis. Improving our understanding of the mechanisms driving gonad development, such as $d n d$ expression, would enable the development of new sex maturation control technologies.

\section{Materials and Methods}

\subsection{Animals and Sampling}

3 females and 3 males which fully matured starry flounders were used in this experiment from Marine seed fish farm (Yeosu, Korea). These fishes were raised in a 15 ton tank controlling the water temperature. The mean total length and weight of females was $33.8 \pm 2.8 \mathrm{~cm}$ and $825.7 \pm 186.5 \mathrm{~g}$. The mean total length and weight of males was were $32.6 \pm 0.9 \mathrm{~cm}$ and $504.6 \pm 87.4 \mathrm{~g}$. Starry flounders were kept on 16:8 light:dark cycle. Exogenous salmon gonadotropin-releasing hormone analog (sGnRHa) (Ovaplant, Syndel, Ferndale, WA, USA) pellets were inserted into the dorsal muscles at a concentration of $50 \mu \mathrm{g} / \mathrm{kg}$. Various tissues including brain, gill, heart, kidney, eye, stomach, gut, spleen, liver, muscle, testis, and ovary were collected from fully matured female and male starry flounders. Fertilized eggs were cultured at $10 \pm 1{ }^{\circ} \mathrm{C}$ after artificial insemination. Embryo samples including unfertilized egg, 1 cell, 2 cell, 4 cell, 8 cell, 16 cell, morula, blastula, early gastrula, late gastrula, somite, and hatching larva were collected for analysis. Tissues and embryos were stored in liquid nitrogen prior to RNA extraction. 


\subsection{Total RNA Extraction and $c D N A$ Synthesis}

Total RNA was extracted followed by the manufacturer's instructions. Total RNA was extracted from $100 \mathrm{mg}$ of each tissue (brain, gill, heart, kidney, eye, stomach, gut, spleen, liver, muscle, testis, and ovary) using TRIzol@(Invitrogen, Waltham, MA, USA). In addition, total RNA was extracted from $100 \mathrm{mg}$ of embryo tissue at 12 distinct developmental stages using TRIzol®reagent. $200 \mu \mathrm{L}$ of chloroform were added and reacted at $-20{ }^{\circ} \mathrm{C}$ for $5 \mathrm{~min}$. Centrifugation at $12,000 \mathrm{rpm}, 4{ }^{\circ} \mathrm{C}$ for $15 \mathrm{~min}$. The supernatant was mixed with the same amount of isopropanol and reacted for $10 \mathrm{~min}$. Centrifuge at $12,000 \mathrm{rpm}, 4{ }^{\circ} \mathrm{C}$ for $10 \mathrm{~min}$. The supernatant was removed and $1 \mathrm{~mL}$ of $70 \%$ ethanol was added for washing the pellet. The ethanol was removed completely by centrifuging at $12,000 \mathrm{rpm}, 4{ }^{\circ} \mathrm{C}$ for $5 \mathrm{~min}$. $100 \mu \mathrm{L}$ of diethylpyrocarbonate (DEPC) water was added to the pellet and resuspended. DNase I (Qiagen, Hilden, Germany) was treated to prevent DNA contamination. cDNA was synthesized from purified total RNA using a Maxima First Strand cDNA Synthesis Kit (Thermo, Waltham, MA, USA). Two microliters of Maxima Enzyme Mix, $4 \mu \mathrm{L}$ of $5 \times$ reaction mix, and $14 \mu \mathrm{L}$ of RNA were mixed for real-time PCR. The cDNA synthesis conditions were $25^{\circ} \mathrm{C}$ for $10 \mathrm{~min}, 65^{\circ} \mathrm{C}$ for $30 \mathrm{~min}$, and $85^{\circ} \mathrm{C}$ for $5 \mathrm{~min}$. The synthesized cDNA was quantified using a NANODROP ONEC (Thermo, Waltham, MA, USA) and stored in a deep freezer $\left(-80^{\circ} \mathrm{C}\right)$.

\subsection{PCR Amplification of cDNA Fragment}

Primers were designed based on the $d n d$ mRNA sequence of olive flounder to detect and amplify psdnd. The olive flounder $d n d$ sequence (Accession No. KP224455.1) was obtained from the National Center for Biotechnology database (Table 1).

Table 1. Primer and probe sequences for $p s d n d$ cloning and qRT-PCR.

\begin{tabular}{|c|c|c|c|}
\hline Purpose & Primer Name & Primer Sequence $\left(5^{\prime}-3^{\prime}\right)$ & Product Size_(bp) \\
\hline \multirow{3}{*}{ Partial fragment } & $d n d-\mathrm{F}$ & ATGAACACTGAGCGGGTGCAAGC & \multirow{2}{*}{1098} \\
\hline & $d n d-\mathrm{R}$ & CTAGTTGTTGTAAATTTCCTGCAGG & \\
\hline & $5^{\prime}$ GSP1 & AGATTGCTTTTGTAAC & $\geq 238$ \\
\hline \multirow{2}{*}{$5^{\prime} \mathrm{RACE}$} & $5^{\prime} \mathrm{GSP} 2$ & AGACAGGCCCCACAGAGCTGAAC & $\geq 145$ \\
\hline & $5^{\prime}$ GSP3 & AGCTGGTCCTCGTAGCTGTCCCGTG & $\geq 113$ \\
\hline \multirow[b]{2}{*}{$3^{\prime} \mathrm{RACE}$} & $3^{\prime}$ GSP1 & GCGTGCAGAACGTTTCACTGACAGCTGGG & $\geq 647$ \\
\hline & $3^{\prime}$ GSP2 & TGCCACATCCTGAAGGCTCCACAGTCCTC & $\geq 408$ \\
\hline \multirow{2}{*}{ Cloning } & CL-F & GCGTGCAGAACGTTTCACTGACAGCTGGG & \multirow{2}{*}{1493} \\
\hline & CL-R & TGCCACATCCTGAAGGCTCCACAGTCCTC & \\
\hline \multirow{2}{*}{ qRT-PCR } & $d n d-\mathrm{qF}$ & AGAACGTTTCACTGACAGC & \multirow{2}{*}{100} \\
\hline & $d n d-\mathrm{qR}$ & AGAACGTTTCACTGACAGC & \\
\hline \multirow{2}{*}{ qRT-PCR } & GAPDH-qF & CCAGAACATCATCCCAGCTT & \multirow[b]{2}{*}{185} \\
\hline & GAPDH-qR & GGCCTTCACAACCTTCTTGA & \\
\hline & WISH-F & AGATCCCACGGGACAGCTAC & \multirow{2}{*}{761} \\
\hline WISH & WISH-R & GTTGGTCAGCCACGCTATGAG & \\
\hline
\end{tabular}

The PCR cycling conditions were as follows: pre-denaturation at $94{ }^{\circ} \mathrm{C}$ for $5 \mathrm{~min}$; 30 cycles of $94{ }^{\circ} \mathrm{C}$ for $30 \mathrm{~s}$, annealing at $55^{\circ} \mathrm{C}$ for $30 \mathrm{~s}$, and extension at $72{ }^{\circ} \mathrm{C}$ for $2 \mathrm{~min}$; then a final extension at $72{ }^{\circ} \mathrm{C}$ for $10 \mathrm{~min}$. The PCR products were analyzed by electrophoresis with a $1 \%$ agarose gel. The DNA was gel extracted and sequenced by Macrogen Inc. (Seoul, Korea).

\section{4. $5^{\prime}$ and $3^{\prime}$ Rapid Amplification of cDNA Ends (RACE) PCR}

$5^{\prime}$ and $3^{\prime}$ gene-specific primers (GSPs) were designed based on the partial fragment of starry flounder $d n d$ to obtain the full transcript (Table 1). $5^{\prime}$ RACE PCR was conducted using a 5' RACE system for Rapid Amplification of cDNA Ends kit version 2.0 (Invitrogen, Waltham, MA, USA), in accordance with the manufacturer's instructions.

3' cDNA was synthesized using a SMART cDNA synthesis kit (Clontech, MountainView, CA, USA). Total RNA was isolated from starry flounder ovarian tissues using 
TRIzol®reagent. Single-step PCR and semi-nested PCR were performed using the synthesized 3' cDNA. One microliter of 3' GSP1 primer, $1 \mu \mathrm{L}$ of universal primer mix, and $2 \mu \mathrm{L}$ of $3^{\prime} \mathrm{cDNA}$ were added to the reaction mixture containing $0.25 \mu \mathrm{L}$ of Advantage Taq polymerase (Takara, Nojihigashi, Japan), $1.5 \mu \mathrm{L}$ of $10 \times$ buffer, $1 \mu \mathrm{L}$ of dNTPs, and sterile water to a total volume of $10 \mu \mathrm{L}$. The single-step PCR cycling conditions were as follows: pre-denaturation at $94{ }^{\circ} \mathrm{C}$ for $2 \min 30 \mathrm{~s} ; 35$ cycles of $94{ }^{\circ} \mathrm{C}$ for $30 \mathrm{~s}$, annealing at $58^{\circ} \mathrm{C}$ for $30 \mathrm{~s}$, and amplification at $72{ }^{\circ} \mathrm{C}$ for $2 \mathrm{~min}$; then a final extension at $72{ }^{\circ} \mathrm{C}$ for $5 \mathrm{~min}$. The semi-nested PCR was conducted with $1 \mu \mathrm{L}$ of nested universal primer, $1 \mu \mathrm{L}$ of 3' GSP2, $1 \mu \mathrm{L}$ of the single-step PCR product, $17 \mu \mathrm{L}$ of $1.1 \times$ master mix, and sterile water to a total volume of $20 \mu \mathrm{L}$. The semi-nested PCR was performed using thermocycling conditions identical to the conditions used for single-step PCR. PCR products were an-alyzed by means of electrophoresis and sequencing, performed by Macrogen Inc. (Seoul, Korea).

\subsection{Cloning}

Primers were designed based on the $1525 \mathrm{bp} p s d n d$ cDNA sequence obtained via $5^{\prime}$ and 3' RACE PCR. One microliter of ovary cDNA was amplified with AccuPower ${ }^{\circledR}$ PCR premix (Bioneer, Deajeon, Korea) and $10 \mathrm{pM}$ of each primer (sense and antisense). The PCR cycling parameters were as follows: initial denaturing at $94{ }^{\circ} \mathrm{C}$ for $5 \mathrm{~min} ; 35$ cycles of denaturing at $94{ }^{\circ} \mathrm{C}$ for $30 \mathrm{~s}$, annealing at $53{ }^{\circ} \mathrm{C}$ for $30 \mathrm{~s}$, and elongation at $72{ }^{\circ} \mathrm{C}$ for $2 \mathrm{~min}$; then a final elongation at $72{ }^{\circ} \mathrm{C}$ for $10 \mathrm{~min}$. PCR products were analyzed on a $1 \%$ agarose gel and DNA within a size range of $1400-1600 \mathrm{bp}$ was extracted using a Gel extraction kit (Bioneer, Korea). cDNA $(30 \mathrm{ng} / \mu \mathrm{L})$ was ligated into the pGEM-T vector system I (Promega, Madison, WI, USA), in accordance with the manufacturer's instructions. Ten microliters of ligation mixture were used to transform $50 \mu \mathrm{L}$ of Escherichia coli DH5 $\alpha$ Competent Cells (Takara, Nojihigashi, Japan), and the cells were incubated at $37^{\circ} \mathrm{C}$ for recovery. The transformation culture was then incubated for $16 \mathrm{~h}$ at $37^{\circ} \mathrm{C}$ on MacConkey agar supplemented with ampicillin for colony selection. Plasmid DNA was extracted using an Accuprep ${ }^{\circledR p}$ plasmid Mini extraction kit (Bioneer, Korea). The extracted plasmid DNA was sequenced by Macrogen Inc. (Seoul, Korea).

\subsection{Phylogenetic Analysis of $p s d n d$}

Molecular phylogenetic analysis was performed to compare the $d n d$ sequences of different vertebrate species. The full $d n d$ gene sequences of various species were retrieved from the NCBI database. The GenBank accession numbers of the sequences examined were as follows: atlantic salmon (Salmo salar), JN712911.1; channel catfish (Ictalurus punctatus), XM_017484732.1; chicken (Gallus gallus), XM_015293536.2; common carp (Cyprinus carpio), XM_019103334.1; atlantic halibut (Hippoglossus hippoglossus), XM_034598806.1; human (Homo sapiens), NM_194249.3; pond loach (Misgurnus anguillicaudatus), MH283870.1; mouse (Mus musculus), NM_173383.2; olive flounder (Paralichthys olivaceus), KP224455.1; pacific bluefin tuna (Thunnus orientalis), KF128758.1; rainbow trout (Oncorhynchus mykiss), MK887177.1; turbot (Scophthalmus maximus), KC460339.1; western clawed frog (Xenopus tropicalis), NM_001044434.1 and zebrafish (Danio rerio), AY225448.1.

A phylogenetic tree was constructed with the Mega $X$ version 10.1 software using the maximum-likelihood method with a bootstrap analysis of 1000 replicates. The percentage identities between the starry flounder $d n d$ sequence and the homologues genes from other species were analyzed with CLUSTALW.

\section{7. $q R T-P C R$}

qRT-PCR was performed using a Pikoreal 96 RealTime PCR System (Thermo, Waltham, MA, USA) to examine the $p s d n d$ expression profiles in various tissues and stages of embryo development. The concentrations of cDNA from eight distinct tissues and 12 developmental stages were adjusted to $50 \mathrm{ng} / \mu \mathrm{L}$ and $500 \mathrm{ng} / \mu \mathrm{L}$ respectively. The primers used for qRTPCR are listed in Table 1. dnd transcripts were detected using SYBR Green PCR Mastermix (Thermo, Waltham, MA, USA), mixed with $1 \mu \mathrm{L}$ of each primer (10 pM), $1 \mu \mathrm{L}$ of cDNA, 
and $7 \mu \mathrm{L}$ of sterile water. The qRT-PCR cycling conditions were as follows: pre-incubation at $50^{\circ} \mathrm{C}$ for $2 \mathrm{~min}$; pre-denaturation at $95^{\circ} \mathrm{C}$ for $7 \mathrm{~min}$; and then 40 cycles of denaturation at $95^{\circ} \mathrm{C}$ for $15 \mathrm{~s}$, annealing at $55^{\circ} \mathrm{C}$ for $30 \mathrm{~s}$, and extension at $72{ }^{\circ} \mathrm{C}$ for $20 \mathrm{~s}$. Expression levels of the housekeeping gene glyceraldehyde3-phosphate dehydrogenase were used to calculate the relative expression levels of $p s d n d$. psdnd expression levels in the spleen and fertilized eggs were used to calculate $\mathrm{Ct}$ values. Relative expression levels were determined by calculating $2^{-\Delta \Delta \mathrm{Ct}}$ using mean $\mathrm{Ct}$ values. The qRT-PCR primer sequences are shown in Table 1.

\subsection{Whole Mount In Situ Hybridization (WISH)}

Digoxigenin-labeled antisense probes were synthesized from linearized plasmids containing the $d n d$ sequence using a DIG RNA Labeling kit (Roche, Basel, Switzerland). The primers used for WISH are shown in Table 1. Embryo samples were fixed in $4 \%$ paraformaldehyde with phosphate-buffered saline. The embryo samples were dehydrated using $50 \%$ and $30 \%$ methanol, and the pigments were removed from the embryo samples using $6 \%$ hydrogen peroxide and $0.5 \%$ potassium hydroxide. Then, proteinase $\mathrm{K}$ solution $(10 \mu \mathrm{g} / \mathrm{mL})$ was applied to permeabilize embryo membranes, and the embryo samples were fixed again in $4 \%$ paraformaldehyde. Samples were incubated in hybridization solution at $65^{\circ} \mathrm{C}$ for $3 \mathrm{~h} ; 1 \mu \mathrm{g} / \mathrm{mL}$ antisense RNA probe was then added to the hybridization solution and incubated at $85^{\circ} \mathrm{C}$ for 3 minutes. A longer hybridization reaction was also conducted at $65^{\circ} \mathrm{C}$ for $12 \mathrm{~h}$. The $d n d$ transcripts were visualized using purple alkaline phosphatase substrate.

\subsection{Statistical Analysis}

The qRT-PCR results were expressed as mean \pm SD. Statistical analyses were performed using SPSS Statistic version 26.0 (SPSS Inc., Chicago, IL, USA). One-way analysis of variance and Tukey's test were used to determine significance $(p<0.05)$.

\section{Results}

\subsection{Identification of P. stellatus $c D N A$ Sequence}

The full-length $p s d n d$ mRNA was $1495 \mathrm{bp}$ long, containing an $1185 \mathrm{bp}$ coding sequence encoding 395 amino acids (Figure 1). psdnd cDNA had five exon regions; the length of exons 1 to 5 were $151 \mathrm{bp}, 111 \mathrm{bp}, 327 \mathrm{bp}, 133 \mathrm{bp}$, and $536 \mathrm{bp}$ respectively. The length of the $5^{\prime}$-untranslated region was $73 \mathrm{bp}$. The $3^{\prime}$-untranslated region was $239 \mathrm{bp}$ long, including the complete $3^{\prime}$ end with a poly-(A)-tail. psdnd genomic DNA had 4 introns with lengths of $1240 \mathrm{bp}, 1001 \mathrm{bp}, 751 \mathrm{bp}$, and 1509 bp (Figure 2). 
1217 GTT G

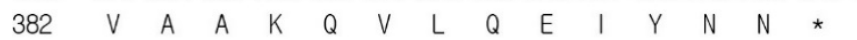

1262 TCC CAG TGA CAA GCT CAT CAG ACG AGA GCT GGC CTC CTC CTG TAT 1307 GCA CTG TTC AAG ACA AAT GTT AAT GTT GTC GAG GTT TGG TAG TTT 1352 ATT TCT GCA TGT TTT TAT TAG AAT AAT AGT TTG TCT TGT TTC AAA 1397 TGT GTG GTT TGT TTA ATG CAT GCT CTC TGT GTG TGT AAG TGT TGG 1442 ATT GTT CCT CCT TTT AAT AAA TGA GAA TTT AAA GTA AAA AAA AAA 1487 AAA AAA AAA

Figure 1. Nucleotide and amino acid sequence of $p s d n d$. The first methionine amino acid indicates the start codon. Strock indicates the stop codon. Amino acid sequence was analyzed by clustal omega website available at https:/ /www.ebi.ac.uk/Tools/msa/clustalo/ (accessed on 15 March 2020). 


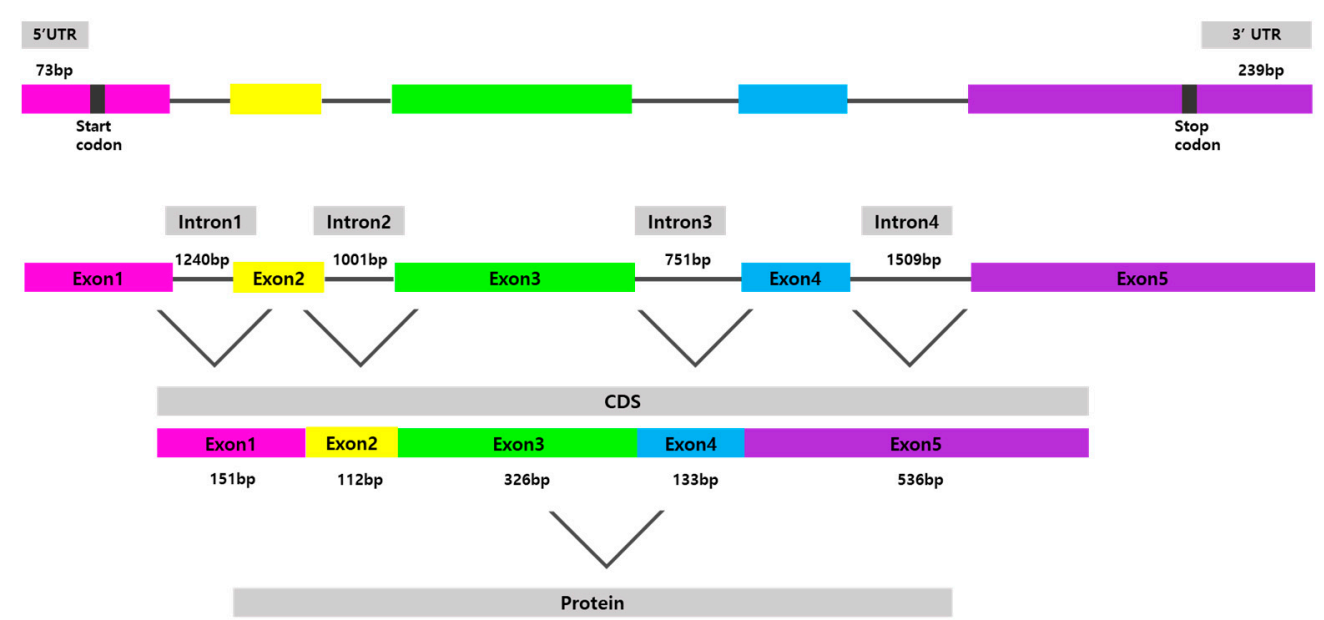

Figure 2. Physical map of cloned $p s d n d$. The $p s d n d$ open reading frame (ORF) contains 5 exons and 4 introns. Revealed 73 bp of 5'UTR and $239 \mathrm{bp}$ of $3^{\prime}$ UTR. Each exons are shown in different color boxes. Introns expressed thin grey lines.

\subsection{Multiple Sequence Alignments}

A multiple alignments comparing the amino acid sequence deduced from $p s d n d$ with the $d n d$ sequences of other species is shown in Figure 3. The range of sequence identities of the $d n d$ amino acid sequences was 31-85\% (Table 2). Of the alignment, data suggested that several regions of the $d n d$ protein were conserved between species. The amino acid sequence determined using the $p s d n d$ cDNA sequence possessed three conserved motifs including two RNA-recognition motifs (RRMs) and one double-stranded RNA-binding motif (DSRM). The RRMs and DSRM were shared among $d n d$ homologues.

Table 2. Sequence identities comparing $p s d n d$ to homologues in other species.

\begin{tabular}{cc}
\hline Species & Identity (\%) \\
\hline Starry flounder (Platichthys stellatus) & 100 \\
Atlantic halibut (Hippoglossus hippoglossus) & 85 \\
Olive flounder (Paralichthys olivaceus) & 77 \\
Turbot (Scophthalmus maximus) & 62 \\
Pacific blufin tuna (Thunnus orientalis) & 61 \\
Rainbow trout (Oncorhynchus mykiss) & 50 \\
Atlantic salmon (Salmo salar) & 49 \\
Pond loach (Misgurnus anguillicaudatus) & 39 \\
Channel catfish (Ictalurus punctatus) & 39 \\
Common carp (Cyprinus carpio) & 37 \\
Zebrafish (Danio rerio) & 35 \\
Human (Homo sapiens) & 33 \\
Mouse (Mus musculus) & 32 \\
Chicken (Gallus gallus) & 32 \\
Western clawed frog (Xenopus tropicalis) & 31 \\
\hline
\end{tabular}




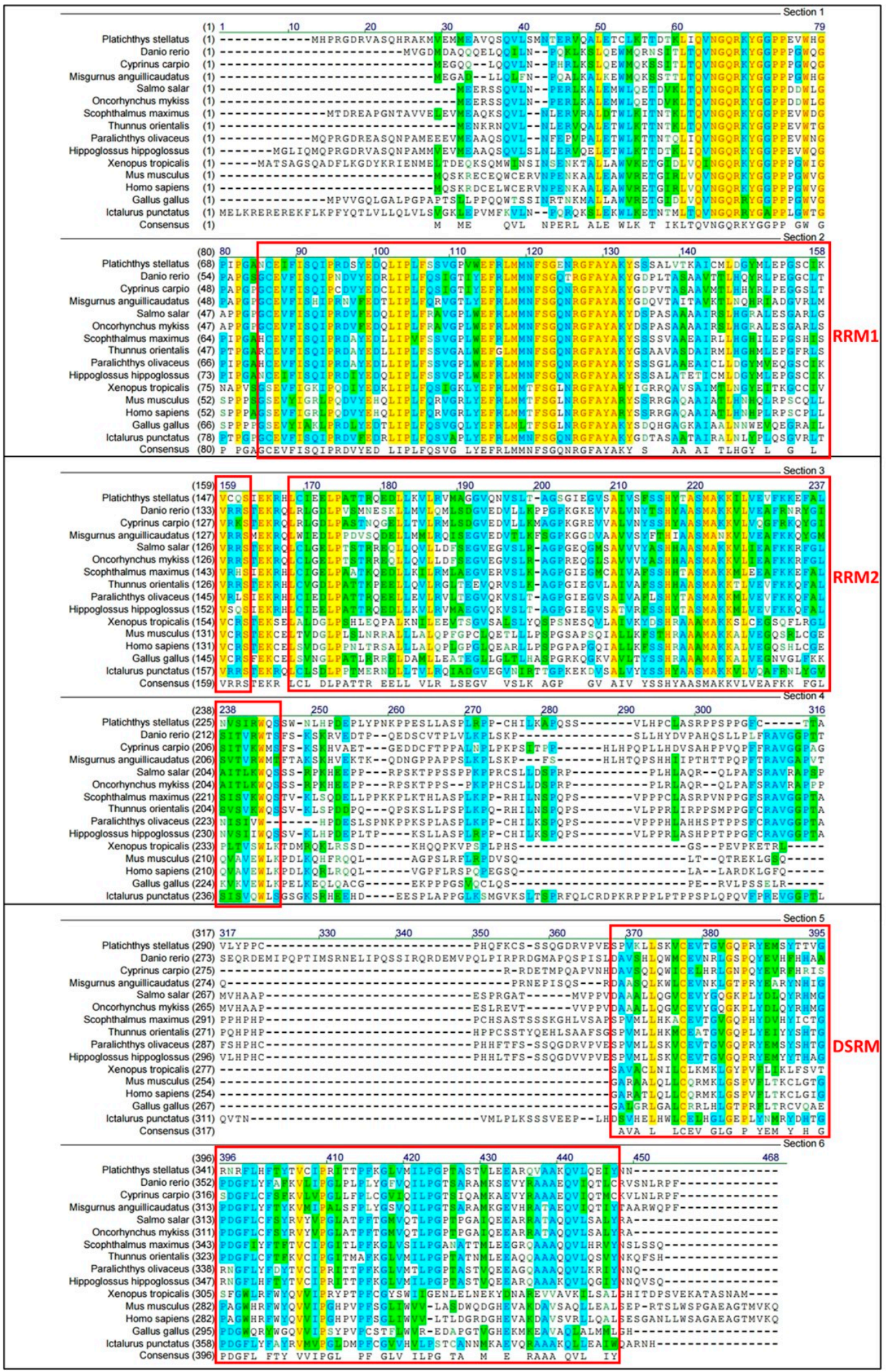

Figure 3. Multiple alignments of $p s d n d$ with $d n d$ homologues from various vertebrate species. Black text on white: non-similar residues. Blue text on cyan: consensus residue, derived from a block of similar residues at a specific position. Black text on green: consensus residue, derived from an occurrence of $\geq 50 \%$ of a single residue at a specific position. Red on yellow: consensus residue, derived from a completely conserved residue at a specific position. Green text on white: residue similar to consensus residue at a specific position. Red boxes indicate conserved motifs including RRM1, RRM2 and, DSRM. Multiple alignment analyzed by align X program. Conserved domain was analyzed at NCBI conserved domain site. 


\subsection{Phylogenetic Tree and Identity}

The deduced $p s d n d$ amino acid sequence was aligned with related protein sequences from various vertebrate species (Table 2). According to the neighbor-joining tree shown in Figure 4, $p s d n d$ and atlantic halibut $d n d$ formed a clade supported by a bootstrap value of $100 \%$. psdnd exhibited identities of $85 \%, 77 \%, 62 \%, 61 \%, 50 \%, 49 \%, 39 \%, 39 \%, 37 \%, 35 \%$, $33 \%, 32 \%, 32 \%$, and $31 \%$ with dnd homologues in atlantic halibut, olive flounder, turbot, pacific bluefin tuna, rainbow trout, Atlantic salmon, pond loach, channel catfish, common carp, zebrafish, human, mouse, chicken, and western clawed frog respectively (Figure 4).

The highest protein sequence identity is $85 \%$ of Atlantic halibut. As followed DND protein identity ranked high $77 \%$ of olive flounder and $62 \%$ of turbot. The lowest protein sequence identity is $31 \%$ of western clawed frog.

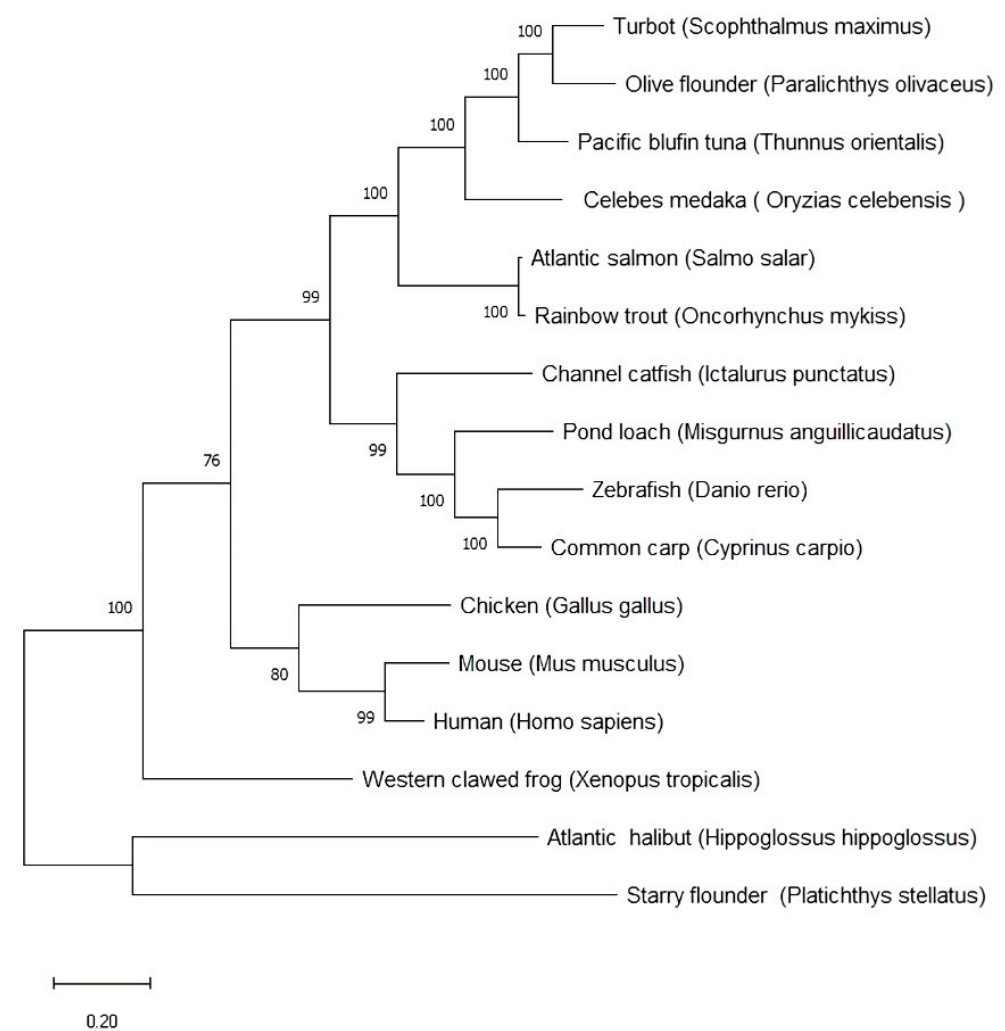

Figure 4. Phylogenetic tree and sequences identities comparing $p s d n d$ with $d n d$ from various vertebrate species. Phylogenetic tree of $p s d n d$ established by MEGAX program with maximum likelihood method. The numbers under the nodes indicate bootstrap percentage values for 1000 replicates. Scale bar indicates number of substitution changes per site. Bootstrap values indicate branch.

\section{4. $q R T-P C R$}

psdnd transcripts were detected in both male and female gonads by means of qRT-PCR. However, $p s d n d$ expression was significantly greater in the ovaries than in the testes. No $p s d n d$ expression was detected in the other tissues examined (Figure 5a).

psdnd mRNA was expressed during all stages of embryonic development and expression was maintained until hatching (Figure $5 b$ ). Strong expression was detected from the fertilized egg stage until the 16 cell stage. After fertilization, $p$ sdnd transcript expression increased and peaked at the 1 cell stage. psdnd expression decreased slightly until 16 cell stage, then decreased dramatically from the 16 cell stage to the hatching stage. 
(a)

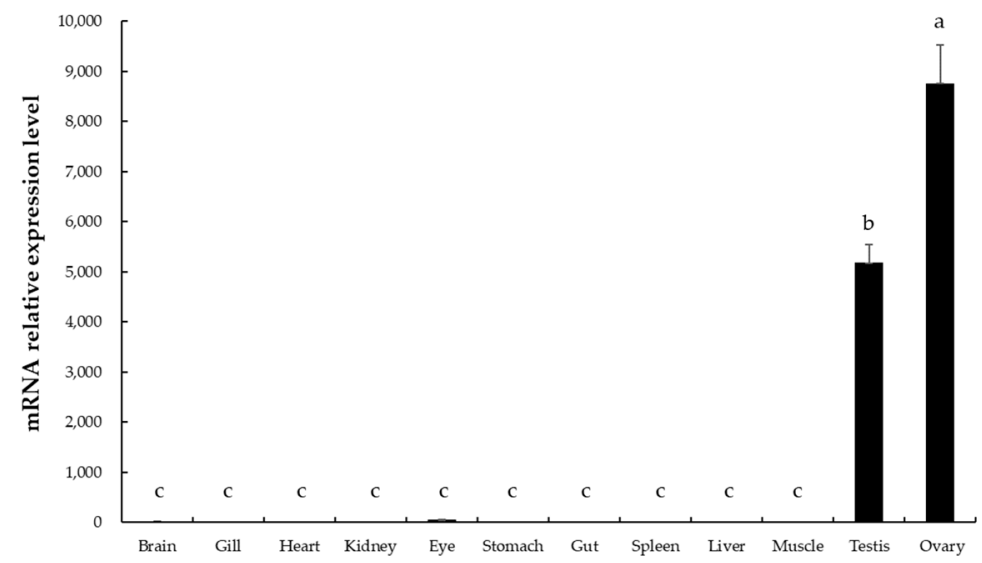

(b)

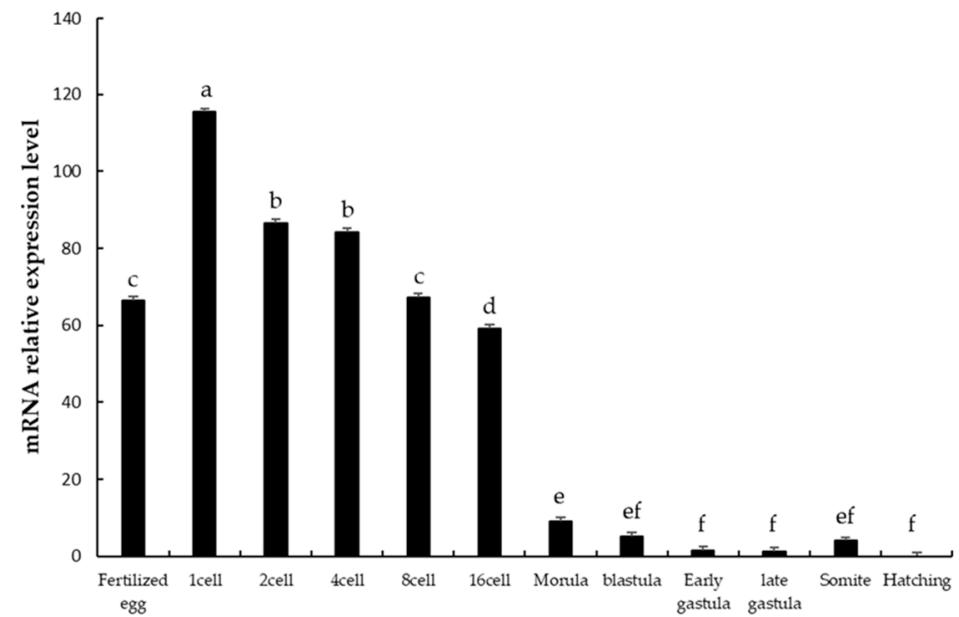

Figure 5. psdnd transcript expression levels in various tissues and embryo stages measured by qRTPCR. (a) Tissue-specific expression of $p s d n d(p<0.05)$. (b) Embryonic expression of $p s d n d$. Different letters indicate statistically significant difference $(p<0.05)$.

\subsection{Whole-Mount In Situ Hybridization}

Two spots of $d$ nd positive cells were detected at the edges of the first furrows during the 2 cell stage (Figure 6a). psdnd was expressed in four spots at the ends of the second furrows from the 4 cell to the morula stage (Figure $6 \mathrm{~b}-\mathrm{d}$ ). At the blastula stage, multiple sister cells were generated close to the psdnd positive-cells (Figure 6e). During the early gastrula stage, $p s d n d$ expression was detected at the blastoderm margins (Figure 6f). At the late gastrula stage, few psdnd transcripts were dispersed however they were on move at the trunk mesoderm (Figure $6 \mathrm{~g}$ ). The $p s d n d$ positive signals then moved toward the dorsal mesentery, where the gonads would later develop; $p s d n d$ expression continued in this area until the hatching stage (Figure 6h,i). 
a
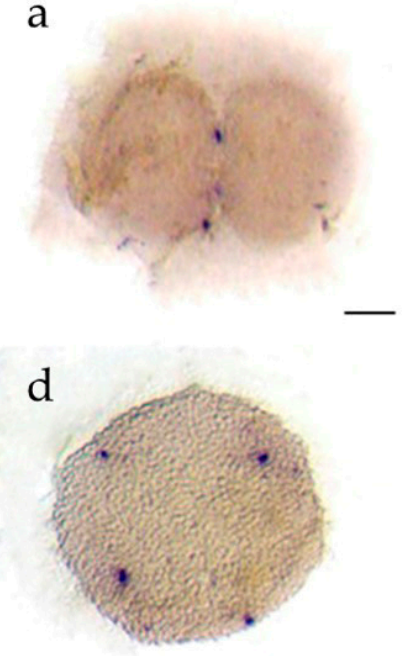

g

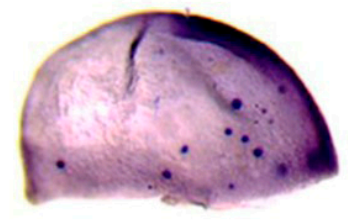

$\mathrm{b}$
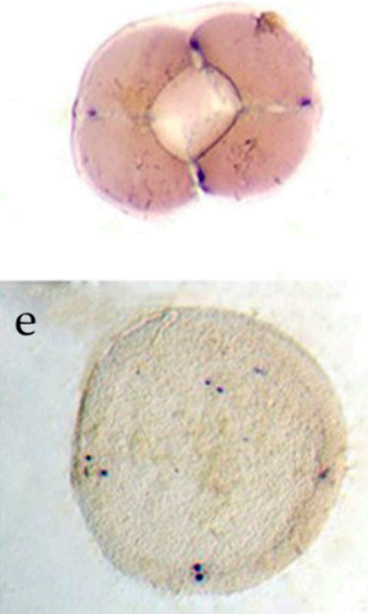

h

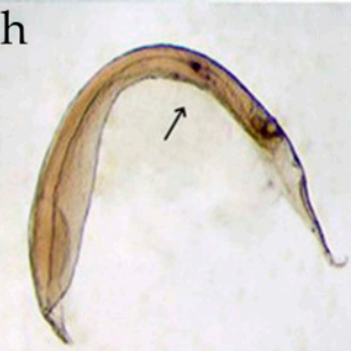

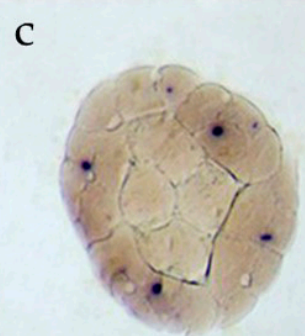

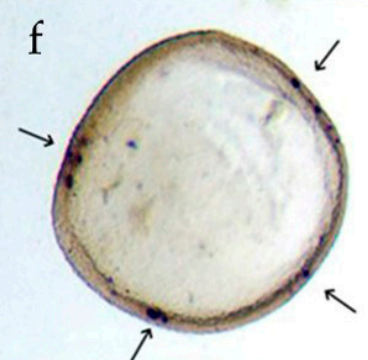

i

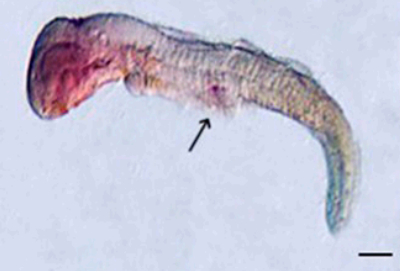

Figure 6. $p s d n d$ transcript localization during embryogenesis. Embryos were hybridized with antisense $p s d n d$, stained by purple AP. (a) 2 cell stage: $p s d n d$ transcripts presented at first cleavage site; (b) 4 cell stage: $p s d n d$ positive signals revealed the spots where edges of second cleavage; (c) 32 cell stage; (d) morula stage: four $d$ nd positive signals maintained until morula stage; (e) blastula stage: sister cells developed next to origin cells; (f) early gastrula stage; $d n d$ transcripts increased and clustered at four spots of germ rings; (g) late gastrula stage; $p s d n d$ positive signals were move on to body axes; (h) early somite stage; (i) hatching larva: psdnd transcripts were aggregated and move on to future gonad location. Arrows indicate $p s d n d$ transcript expression. Scale bar: $100 \mu \mathrm{m}$.

\section{Discussion}

In this study, the $p s d n d$ protein sequence contains two RRM motif and one DSRM motif at its C-terminus, which are characteristic of DND protein [1]. The interspecific similarities in the DND amino acid sequences suggest that they have similar structures and functions, and that DND is well conserved. The first RRM motif, RRM1, is the main binding site for DND1 protein that directly binds to nanos1. The second RRM motif, RRM2, plays a role in promoting nanos1 translation and germline survival in xenopus [26]. DSRM is not essential for RNA binding, although it increases the target specificity of the RRM regions in DND1 in human [27]. Zebrafish $d n d$ has a binding site to bind miR-430 for preventing degradation from miRNA [8]. However, the structure and function of which has not been evaluated in starry flounder. Further study is needed to understand the relationship between $p s d n d$ and miR-430 in starry flounder.

The $p s d n d$ protein sequence exhibited strong homologues with DND proteins of other species, especially other flatfish species such as Atlantic halibut $(85 \%)$, olive flounder (77\%), and turbot $(62 \%)$. The phylogenetic tree and identity results indicated that $d n d$ in starry flounder and Atlantic halibut have the highest evolutionary closeness in our researched target species.

The transcript expression of $p s d n d$ was analyzed in various tissues by means of qRTPCR. psdnd expression was only detected in the ovaries and testes, suggesting that $p s d n d$ can be used as a germ cell marker in starry flounder. In some species, such as mouse 
and xenopus, $d n d$ expression is sex-dependent $[13,28]$. However, in fish species, $d n d$ is expressed in both sexes, as observed in this study $[7,13,18,29,30]$. The expression in both ovary and testis means $p s d n d$ has specific roles for oogenesis and spermatogenesis during sexual maturation in starry flounder.

The expression levels of $p s d n d$ at various embryo developmental stages were also investigated by qRT-PCR. We found that $p$ sdnd was highly expressed during the early developmental stages, from the 1 cell to the early gastrula stage. Higher expression patterns during early embryogenesis also revealed in olive flounder and turbot $[7,28]$. This suggests that embryonic $p$ sdnd expression is of maternal origin, similar with the germplasm marker, vasa. psdnd was also detected at the zygote stage. After the gastrula stage, $p s d n d$ transcripts began to decrease more dramatically. Maternal genes are often highly expressed until the zygotic genome is activated. Depending on the genes or species, continuously sex-pressed gene can interact with the zygotic genome [31]. The pattern of $p s d n d$ expression pattern may be related to the expression of the microRNA 430. MicroRNAs are small molecules that regulate the expression of target mRNAs by degradation. In zebrafish, miR-430 targets nanos and $t d r d 7$, which are essential for PGC development. DND1 prevents miR-430 from binding to its target mRNAs. After zygotic genome activation at the gastrula stage, miR-430 and DND1 expression levels decrease [8,32,33]. In this study, we found that $p s d n d$ was strongly expressed before the blastula stage, suggesting that $p s d n d$ was of maternal origin.

The successful migration of PGCs to the gonads is essential for PGC development and survival. PGCs require maternally supplied germplasm and mRNAs for their specification and maintenance. Our WISH results revealed that the $p s d n d$ expression pattern was similar with the PGC localization pattern, suggesting that $p s d n d$ is a germplasm involved in PGC migration. Similar quantitative and spatial expression patterns occur for $d n d$ in other vertebrate species, including olive flounder, turbot, and rare minnow $[7,30,31]$.

This finding of this study suggests that $p s d n d$ could be used as a germ cell marker in starry flounder; moreover, $d n d$ could be a potential target for starry flounder sterilization.

\section{Conclusions}

In this study, we identified and cloned full-length $p s d n d$, which was $1495 \mathrm{bp}$ long and encoded 395 amino acids. $p s d n d$ was specifically expressed in starry flounder ovaries and testes. Moreover, $p s d n d$ was highly expressed during the early embryonic developmental stages, from fertilized egg to the 16 cell stage, after which expression significantly decreased. Our results suggest that $p s d n d$ is maternally derived and specifically expressed in germ cells, similar with $d n d$ homologs in organisms.

Author Contributions: Conceptualization, J.-H.Y.; methodology, Y.-S.C. and J.-H.Y.; software, J.-H.Y., Y.-S.C.; formal analysis, J.-H.Y., Y.-S.C., H.-B.L. and J.-Y.P.; data curation, J.-H.Y.; writing—original draft preparation, J.-H.Y.; supervision, H.-K.L.; project administration, H.-K.L.; funding acquisition, H.-K.L. All authors have read and agreed to the published version of the manuscript.

Funding: This research was funded by the Korean Institute of Marine Science \& Technology Promotion, Republic of Korea, with Assignment No. 20180373. This research was conducted as part of the project entitled "Establishing a foundation for the year-round production of flatfish eggs and improving productivity".

Institutional Review Board Statement: The study was approved by the Institutional Animal Care and Use Committee of Mokpo National University No. 1183 (17 December 2013).

Informed Consent Statement: Not applicable.

Data Availability Statement: All data are contained within the article.

Acknowledgments: The authors would like to thank Jum Sook Chung, Ten-Tsao Wong, and Jun Hyung Ryu, University of Maryland Baltimore County for methodological support and allowing us to work on University of Maryland. We thank Il Young Lee for support the resources.

Conflicts of Interest: The authors declare no conflict of interest. 


\section{References}

1. Baloch, A.R.; Franěk, R.; Saito, T.; Pšenička, M. Dead-end (dnd) protein in fish-A review. Fish. Physiol. Biochem. 2019, 47, 1-8. [CrossRef] [PubMed]

2. Marlow, F. Primordial germ cell specification and migration. F1000Research 2015, 4. [CrossRef] [PubMed]

3. Beer, R.L.; Draper, B.W. nanos3 maintains germline stem cells and expression of the conserved germline stem cell gene nanos2 in the zebrafish ovary. Dev. Biol. 2013, 374, 308-318. [CrossRef] [PubMed]

4. Komiya, T.; Itoh, K.; Ikenishi, K. Isolation and characterization of a novel gene of the DEAD box protein family which is specifically expressed in germ cells of Xenopus laevis. Dev. Biol. 1994, 162, 354-363. [CrossRef] [PubMed]

5. Huang, H.Y.; Houwing, S.; Kaaij, L.J. Tdrd1 acts as a molecular scaffold for Piwi proteins and piRNA targets in zebrafish. EMBO J. 2011, 30, 3298-3308. [CrossRef]

6. Anderson, R.A.; Fulton, N.; Cowan, G. Conserved and divergent patterns of expression of DAZL, VASA and OCT4 in the germ cells of the human fetal ovary and testis. BMC Dev. Biol. 2007, 7, 136. [CrossRef] [PubMed]

7. Wang, X.; Liu, Q.; Xiao, Y.; Yang, Y.; Wang, Y.; Song, Z.; You, F.; An, H.; Xiao, Z.; Xu, S. The dnd RNA identifies germ cell origin and migration in olive flounder (Paralichthys olivaceus). BioMed Res. Int. 2015, 2015, 428591.

8. Kedde, M.; Strasser, M.J.; Boldajipour, B.; Oude Vrielink, J.A.F.; Slanchev, K.; le Sage, C.; Nagel, R.; Voorhoeve, P.M.; van Duijse, J.; Ørom, U.A.; et al. RNA-Binding Protein Dnd1 Inhibits MicroRNA Access to Target mRNA. Cell 2007, 131, 1273-1286. [CrossRef]

9. Bhattacharya, C.; Aggarwal, S.; Zhu, R. The mouse dead-end gene isoform $\alpha$ is necessary for germ cell and embryonic viability. Biochem. Biophys. Res. Commun. 2007, 355, 194-199. [CrossRef]

10. Shinomiya, A.; Tanaka, M.; Kobayashi, T.; Nagahama, Y.; Hamaguchi, S. The vasa-like gene, olvas, identifies the migration path of primordial germ cells during embryonic body formation stage in the medaka, Oryzias latipes. Dev. Growth Differ. 2000, 42, 317-326. [CrossRef]

11. Aramaki, S.; Sato, F.; Kato, T.; Soh, T.; Kato, Y.; Hattori, M.A. Molecular cloning and expression of dead end homologue in chicken primordial germ cells. Cell Tissue Res. 2007, 330, 45-52. [CrossRef] [PubMed]

12. Weidinger, G.; Stebler, J.; Slanchev, K.; Dumstrei, K.; Wise, C.; Lovell-Badge, R.; Thisse, C.; Thisse, B.; Raz, E. Dead end, a Novel Vertebrate Germ Plasm Component, Is Required for Zebrafish Primordial Germ Cell Migration and Survival. Curr. Biol. 2003, 13, 1429-1434. [CrossRef]

13. Liu, L.; Hong, N.; Xu, H.; Li, M.; Yan, Y.; Purwanti, Y.; Yi, M.; Li, Z.; Wang, L.; Hong, Y. Medaka dead end encodes a cytoplasmic protein and identifies embryonic and adult germ cells. Gene Expr. Patterns 2009, 9, 541-548. [CrossRef] [PubMed]

14. Fujimoto, T.; Nishimura, T.; Goto-Kazeto, R.; Kawakami, Y.; Yamaha, E.; Arai, K. Sexual dimorphism of gonadal structure and gene expression in germ cell-deficient loach, a teleost fish. Proc. Natl. Acad. Sci. USA 2010, 107, 17211-17216. [CrossRef] [PubMed]

15. Goto, R.; Saito, T.; Takeda, T.; Fujimoto, T.; Takagi, M.; Arai, K.; Yamaha, E. Germ cells are not the primary factor for sexual fate determination in goldfish. Dev. Biol. 2012, 370, 98-109. [CrossRef] [PubMed]

16. Horvay, K.; Claußen, M.; Katzer, M.; Landgrebe, J.; Pieler, T. Xenopus Dead end mRNA is a localized maternal determinant that serves a conserved function in germ cell development. Dev. Biol. 2006, 291, 1-11. [CrossRef]

17. Wong, T.T.; Zohar, Y. Production of reproductively sterile fish by a non-transgenic gene silencing technology. Sci. Rep. 2015, 5, 15822. [CrossRef]

18. Hallerman, E.M.; Kapuscinski, A.R. Incorporating risk assessment and risk management into public policies on genetically modified finfish and shellfish. Aquaculture 1995, 137, 9-17. [CrossRef]

19. Bartley, D.M.; Rana, K.; Immink, A.J. The use of inter-specific hybrids in aquaculture and fisheries. Rev. Fish. Biol. Fish. 2000, 10, 325-337. [CrossRef]

20. Rahman, M.A.; Uehara, T.; Lawrence, J.M. Growth and heterosis of hybrids of two closely related species of Pacific sea urchins (Genus Echinometra) in Okinawa. Aquaculture 2005, 245, 121-133. [CrossRef]

21. Kalsoom, U.; Salim, M.; Shahzadi, T.; Barlas, A. Growth performance and feed conversion ratio (FCR) in hybrid fish (Catla catle x Labeo rohita) fed on feed bran, rice broken and blood meal. Pak. Vet. J. 2009, 29, 55-58.

22. Exadactylos, A.; Arvanitoyannis, I.S. Aquaculture Biotechnology for enhanced fish production for food consumption. In Microbial Biotechnology in Agriculture and Aquaculture, 2nd ed.; Ray, R.C., Ed.; Science Publishers Inc.: Enfield, NH, USA, 2006 ; pp. 453-510.

23. Li, H.; Su, B.; Qin, G.; Ye, Z.; Elaswad, A.; Alsaqufi, A.; Perera, D.A.; Qin, Z.; Odin, R.; Vo, K. Repressible transgenic sterilization in channel catfish, Ictalurus punctatus, by knockdown of primordial germ cell genes with copper-sensitive constructs. Mar. Biotechnol. 2018, 20, 324-342. [CrossRef]

24. Wargelius, A.; Leininger, S.; Skaftnesmo, K.O.; Kleppe, L.; Andersson, E.; Taranger, G.L.; Schulz, R.W.; Edvardsen, R.B. Dnd knockout ablates germ cells and demonstrates germ cell independent sex differentiation in Atlantic salmon. Sci. Rep. 2016, 6, 21284. [CrossRef] [PubMed]

25. Linhartová, Z.; Saito, T.; Kašpar, V.; Rodina, M.; Prášková, E.; Hagihara, S.; Pšenička, M. Sterilization of sterlet Acipenser ruthenus by using knockdown agent, antisense morpholino oligonucleotide, against dead end gene. Theriogenology 2015, 84, 1246-1255. [CrossRef]

26. Aguero, T.; Jin, Z.; Owens, D.; Malhotra, A.; Newman, K.; Yang, J.; King, M.L. Combined functions of two RRMs in Dead-end1 mimic helicase activity to promote nanos1 translation in the germline. Mol. Reprod. Dev. 2018, 85, 896-908. [CrossRef] [PubMed] 
27. Duszczyk, M.M.; Wischnewski, H.; Kazeeva, T.; Loughlin, F.E.; von Schroetter, C.; Pradère, M.U.; Ciaudo, C.; Allain, F.H.T. The solution structure of Dead End bound to AU-rich RNA reveals an unprecedented mode of tandem RRM-RNA recognition required for mRNA repression. BioRxiv 2019, 572156. [CrossRef]

28. Liu, W.; Collodi, P. Zebrafish dead end possesses ATPase activity that is required for primordial germ cell development. FASEB J. 2010, 24, 2641-2650. [CrossRef]

29. Lin, F.; Zhao, C.Y.; Xu, S.H.; Ma, D.Y.; Xiao, Z.Z.; Xiao, Y.S.; Xu, C.A.; Liu, Q.H.; Li, J. Germline-specific and sexually dimorphic expression of a dead end gene homologue in turbot (Scophthalmus maximus). Theriogenology 2013, 80, 665-672. [CrossRef] [PubMed]

30. Duan, J.; Feng, G.; Chang, P.; Zhang, X.; Zhou, Q.; Zhong, X.; Qi, C.; Xie, S.; Zhao, H. Germ cell-specific expression of dead end (dnd) in rare minnow (Gobiocypris rarus). Fish. Physiol. Biochem. 2015, 41, 561-571. [CrossRef]

31. Omura, C.S.; Lott, S.E. The conserved regulatory basis of mRNA contributions to the early Drosophila embryo differs between the maternal and zygotic genomes. PLoS Genet. 2020, 16, e1008645. [CrossRef]

32. Mishima, Y.; Giraldez, A.J.; Takeda, Y.; Fujiwara, T.; Sakamoto, H.; Schier, A.F.; Inoue, K. Differential Regulation of Germline mRNAs in Soma and Germ Cells by Zebrafish miR-430. Curr. Biol. 2006, 16, 2135-2142. [CrossRef] [PubMed]

33. Giraldez, A.J.; Mishima, Y.; Rihel, J.; Grocock, R.J.; Van Dongen, S.; Inoue, K.; Enright, A.J.; Schier, A.F. Zebrafish MiR-430 promotes deadenylation and clearance of maternal mRNAs. Science 2006, 312, 75-79. [CrossRef] [PubMed] 